\title{
LENGTH-WEIGHT RELATIONS OF 15 DEEP-SEA FISH SPECIES (ACTINOPTERYGII) FROM THE NORTH-WESTERN AFRICAN CONTINENTAL SLOPE
}

\author{
César MEINERS-MANDUJANO ${ }^{1 *}$, Lourdes FERNÁNDEZ-PERALTA ${ }^{2}$, Abdelmalek FARAJ ${ }^{3}$, \\ and Ramón GARCÍA-CANCELA ${ }^{2}$ \\ ${ }^{1}$ Instituto de Ciencias Marinas y Pesquerías, Universidad Veracruzana, Veracruz, Mexico \\ ${ }^{2}$ Centro Oceanográfico de Málaga, Instituto Español de Oceanografía, Fuengirola, Spain \\ ${ }^{3}$ Institut National de Recherche Halieutique, Casablanca, Morocco
}

\begin{abstract}
Meiners-Mandujano C., Fernández-Peralta L., Faraj A., García-Cancela R. 2018. Length-weight relations of 15 deep-sea fish species (Actinopterygii) from the north-western African continental slope. Acta Ichthyol. Piscat. 48 (2): 195-198.
\end{abstract}

\begin{abstract}
Length-weight relations (LWR) of 15 teleost fish species from deep waters off the NW African coast were estimated. In total, 4045 specimens, representing 12 families and 15 species, were caught and studied. The following species were covered: Alepocephalus bairdii Goode et Bean, 1879; Beryx decadactylus Cuvier, 1829; Beryx splendens Lowe, 1834; Schedophilus ovalis (Cuvier, 1833); Diretmichthys parini (Post et Quéro, 1981); Micromesistius poutassou (Risso, 1827); Lophius vaillanti Regan, 1903; Mora moro (Risso, 1810); Scorpaena elongata Cadenat, 1943; Trachyscorpia echinata (Köhler, 1896); Helicolenus dactylopterus (Delaroche, 1809); Gephyroberyx darwinii (Johnson, 1866); Aphanopus carbo Lowe, 1839; Zenopsis conchifer (Lowe, 1852); Zeus faber Linnaeus, 1758. The values of the parameter $b$ remained mostly within the expected range of 2.5-3.5. This study provides the first published LWR for five fish species, contributing to the first four references on the LWR for this area. It also presents new maximum lengths for two fish species.
\end{abstract}

Keywords: deep-sea fish, LWR, NW Africa

\section{INTRODUCTION}

Length-weight relations (LWR) are basic tools for fishery research to estimate the mean weight of a certain length class, converting growth-in-length equations to growth-in-weight, estimating biomass from length data, and comparing relative conditions between different regions (Wootton 1990, Maguire and Mace 1993, Pauly 1993, Moutopoulos and Stergiou 2002). The LWRs are also useful for performing morphometric comparisons among species and populations (Petrakis and Stergiou 1995, Gonçalves et al. 1997, Koutrakis and Tsikliras 2003, Froese 2006).

The NW African system is one of the four most productive marine regions in the world for industrial and artisanal fisheries; the overall marine catch of this region approximates 2 million tonnes (Arístegui et al. 2009) and over the last two decades, the deep-water fisheries have gained importance. However, the published LWR studies are very scarce for fishes from this region. This is especially true for fishes inhabiting deep waters along the shelf edge and the continental slope (Rosa et al. 2006, Ferreira et al. 2008, Pereira et al. 2012).
This study provides the first estimates of LWRs for five fish species and contributes first four LWR references for NW Africa. Finally, to the best of our knowledge, this study presents new maximum lengths for two fish species.

\section{MATERIALS AND METHODS}

The length-weight data were taken from 1) three deepsea bottom trawl fishing surveys MAROC carried out in the Moroccan Exclusive Economic Zone (EEZ) along the Atlantic coast of Morocco and Western Sahara during November-December from 2004 to 2006, and 2) scientific observer's records, taken during four fishing trips, BOUMAU, on board Spanish commercial bottom trawlers in Mauritanian waters, in January, February, May, and June of 2007. The combined data covered almost the entire area of the NW African system (covered area of $110500 \mathrm{~km}^{2}$ ), from $36^{\circ} \mathrm{N}$ to $17^{\circ} \mathrm{N}$, with hauls at depths ranging from 500 to $2000 \mathrm{~m}$. The detailed description and complementary data of sampling procedures, location, and trawling depth are available in Déniz-González et al. (2014). 
The specimens were measured to the nearest $0.1 \mathrm{~cm}$ for total length (TL) and weighed to the nearest gram. The LWR for total body weight was calculated based on the Ricker (1973) model

$$
W=a \cdot L^{b}
$$

where $W$ is the body weight $[\mathrm{g}], L$ is the TL $[\mathrm{cm}], a$ is a coefficient related to body form, and $b$ is an exponent indicating the somatic growth type. The parameters $a$ and $b$ were estimated by the least-square method applied to the log-transformed data as

$$
\log W=\log a+b \cdot \log L
$$

where $a$ is the intercept of the regression and $b$ is the slope (Le Cren 1951). The 95\% confidence intervals for $b$ (CI 95\%) were calculated to determine if the hypothetical value of isometry (3) fell between these intervals (Froese 2006). The determination of the coefficient $\left(r^{2}>0.95\right)$ and its statistical significance were used to establish the quality of fit.

\section{RESULTS}

In total, 4045 specimens, representing 12 families and 15 species, were caught and studied. The following species were covered: Alepocephalus bairdii Goode et Bean, 1879; Beryx decadactylus Cuvier, 1829; Beryx splendens Lowe, 1834; Schedophilus ovalis (Cuvier, 1833); Diretmichthys parini (Post et Quéro, 1981); Micromesistius poutassou (Risso, 1827); Lophius vaillanti Regan, 1903; Mora moro (Risso, 1810); Scorpaena elongata Cadenat, 1943; Trachyscorpia echinata (Köhler, 1896); Helicolenus dactylopterus (Delaroche, 1809); Gephyroberyx darwinii (Johnson, 1866); Aphanopus carbo Lowe, 1839; Zenopsis conchifer (Lowe, 1852); Zeus faber Linnaeus, 1758. The most numerous species $(n>100)$ were (in decreasing order): Aphanopus carbo, Lophius vaillanti, Mora moro, Trachyscorpia echinata, Helicolenus dactylopterus, Alepocephalus bairdii, Gephyroberyx darwinii, and Zenopsis conchifer. The statistical description with all the parameters obtained from LWR by species is shown in Table 1.

Linear regressions of the log-transformed relation between TL and $W$ were highly significant for all species $(P<0.001)$. The coefficients of determination $\left(r^{2}\right)$ ranged from 0.954 for Micromesistius poutassou to 0.995 for Schedophilus ovalis. The exponent $b$ ranged from 2.731 for Zeus faber to 3.460 for Schedophilus ovalis, and the intercept value from 0.0004 for Aphanopus carbo to 0.0402 for Zeus faber. Considering the somatic type of growth, seven species showed isometric growth $(b=3)$, two negative cases of allometry $(b<3)$, and six positive ones $(b>3)$. The estimated parameters for Scorpaena elongata, Lophius vaillanti, Gephyroberyx darwinii, and Schedophilus ovalis should be considered the mean annual values since the data were collected from January to June (BOUMAU surveys indicated in Table 1), and they were not representative of any particular season.
On the other hand, the parameters for the remainder of the species should be considered as autumn values because the data were collected exclusively during November and the beginning of December.

\section{DISCUSSION}

The $b$ values of Helicolenus dactylopterus and Gephyroberyx darwinii in the presently reported study differs significantly from those reported in Cape Verde (Pereira et al. 2012), as well as the case of Zenopsis conchifer in Algarve (Borges et al. 2003). In addition, the $b$ values for Beryx decadactylus, Mora moro, and Zeus faber showed strong discrepancies, without being significant, with those estimated for Cape Verde (Pereira et al. 2012), the Gulf of Cadiz (Torres et al. 2012), and Madeira(Ferreira et al.2008), respectively. The differences estimated for Helicolenus dactylopterus, Gephyroberyx darwinii, Mora moro, and Zenopsis conchifer are likely due to size range induced by the selectivity of the longline used in Cape Verde and Madeira compared with corresponding sizes caught by trawl net used in this study, as well the sampling depth in Algarve $(<500 \mathrm{~m})$ that excludes adult specimens. On the other hand, Zeus faber showed a lower $b$ value compared to the value obtained in the Gulf of Cadiz (Torres et al. 2012) and the eastern Adriatic (Dulčić and Kraljević 1996), probably indicating that the species was in worse condition during autumn in NW Africa. The case of Beryx decadactylus is inconclusive, since both the size range and the correlation coefficient of the LWR (0.938) are low for the samples caught in Cape Verde (15) and in the presently reported study as according to Froese et al. (2011).

This study provides the first information on LWR for Diretmichthys parini, Schedophilus ovalis, Lophius vaillanti, Scorpaena elongata, and Trachyscorpia echinata (Table 1, species in bold). This is also the first record of LWR for the Alepocephalus bairdii, Micromesistius poutassou, Zenopsis conchifer, and Zeus faber species in NW Africa. In the case of Schedophilus ovalis, it is important to point out that our estimate, in spite of it being the first available LWR estimate, has a known bias because of the absence of small individuals of this species in the samples. The LWR should thus be used to estimate weights only for specimens greater $37 \mathrm{~cm}$ in TL. Finally, this study provides new maximum sizes for Lophius vaillanti ( $80.3 \mathrm{~cm} \mathrm{TL})$ and for Trachyscorpia echinata $(56.9 \mathrm{~cm} \mathrm{TL})$.

\section{ACKNOWLEDGEMENTS}

The authors would like to thank the crew members of $\mathrm{R} / \mathrm{V}$ Vizconde de Eza, and the scientific and technical staff of the Instituto Español de Oceanografía - Institut National de Recherche Halieutique who helped us collect the biological sampling data used in this cooperative study. We also thank the Spanish commercial trawlers involved and the onboard observer programme deployed in Mauritania. Finally, the first author wishes to thank the Mexican "Consejo Nacional de Ciencia y Tecnología" for financial support through the postgraduate grant (No. 123039). 
$\frac{0}{\frac{0}{0}}$

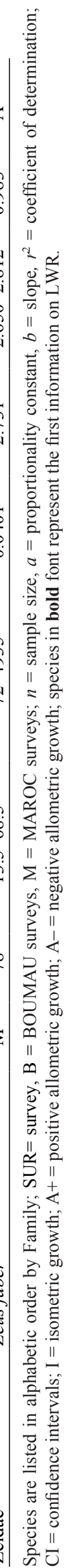




\section{REFERENCES}

Arístegui J., Barton E.D., Álvarez-Salgado X.A., Santos A.M.P., Figueiras F.G., Kifani S., Hernández-León S., Mason E., Machú E., Demarcq H. 2009. Subregional ecosystem variability in the Canary Current upwelling. Progress in Oceanography 83 (1-3): 3348. DOI: $10.1016 /$ j.pocean.2009.07.031

Borges T.C., Olim S., Erzini K. 2003. Weight-length relationship for fish species discarded in commercial fisheries of the Algarve (southern Portugal). Journal of Applied Ichthyology 19 (6): 394-396. DOI: 10.1111/j.1439-0426.2003.00480.x

Déniz-González I., Pascual-Alayón P.J., Chioua J., García-Santamaría M.T., Valdés J.L. 2014. Directory of atmospheric, hydrographic and biological datasets for the Canary Current Large Marine Ecosystem. IOC Technical Series No. 110. IOC-UNESCO, Paris.

Dulčić, J., Kraljević M. 1996. Weight-length relationship for 40 fish species in the eastern Adriatic (Croatian waters). Fisheries Research 28 (3): 243-251. DOI: 10.1016/0165-7836(96)00513-9

Ferreira S., Sousa R., Delgado J., Carvalho D., Chada T. 2008. Weight-length relationships for demersal fish species caught off the Madeira archipelago (easterncentral Atlantic). Journal of Applied Ichthyology 24 (1): 93-95. DOI: 10.1111/j.1439-0426.2007.01027.x

Froese R. 2006. Cube law, condition factor and weightlength relationships: History, meta-analysis and recommendations. Journal of Applied Ichthyology 22 (4): 241-253. DOI: 10.1111/j.1439-0426.2006.00805.x

Froese R., Tsikliras A.C., Stergiou K.I. 2011. Editorial note on weight-length relations of fishes. Acta Ichthyologica et Piscatoria 41 (4): 261-263. DOI: 10.3750/AIP2011.41.4.01

Gonçalves J.M.S., Bentes L., Lino P.G., Ribeiro J., Canário A.V.M., Erzini K. 1997. Weight-length relationships for selected fish species of the smallscale demersal fisheries of the south and south-west coast of Portugal. Fisheries Research 30 (3): 253-256. DOI: $10.1016 / \mathrm{S} 0165-7836(96) 00569-3$

Koutrakis E.T., Tsikliras A.C. 2003. Length-weight relationships of fishes from three northern Aegean estuarine systems (Greece). Journal of Applied Ichthyology 19 (4): 258-260. DOI: 10.1046/j.14390426.2003.00456.x
Le Cren E.D. 1951. The length-weight relationship and seasonal cycle in gonad weight and condition in the perch (Perca fluviatilis). Journal of Animal Ecology 20 (2): 201-219. DOI: 10.2307/1540

Maguire J.J., Mace P.M. 1993. Biological reference points for Canadian Atlantic gadoid stocks. Pp. 321-331. In: Smith S.J., Hunt J.J., Rivard D. (eds.) Risk evaluation and biological reference points for fisheries management. Canadian Special Publication of Fisheries and Aquatic Sciences No. 120.

Moutopoulos D., Stergiou K. I. 2002. Length-weight and length-length relationships of fish species from the Aegean Sea (Greece). Journal of Applied Ichthyology 18 (3): 200-203. DOI: 10.1046/j.14390426.2002.00281.x

Pauly D. 1993. Fishbyte section editorial. Naga, ICLARM Q. 16: 26.

Pereira J. N., Simas A., Rosa A., Aranha A., Lino S., Constantino E., Monteiro V., Tariche O., Menezes G. 2012. Weight-length relationships for 27 demersal fish species caught off the Cape Verde archipelago (eastern North Atlantic). Journal of Applied Ichthyology 28 (1): 156-159. DOI: 10.1111/j.1439-0426.2011.01915.x

Petrakis G., Stergiou K.I. 1995. Weight-length relationships for 33 fish species in Greek waters. Fisheries Research 21 (3-4): 465-469. DOI: 10.1016/0165-7836(94)00294-7

Ricker W.E. 1973. Linear regressions in fishery research. Journal of Fisheries Research Board of Canada 30 (3): 409-434. DOI: 10.1139/f73-072

Rosa A., Menezes G., Melo O., Pinho M.R. 2006. Weight-length relationships of 33 demersal fish species from Azores archipelago. Fisheries Research 80 (2-3): 329-332. DOI: 10.1016/j.fishres.2006.05.001

Torres M.A., Ramos F., Sobrino I. 2012. Length-weight relationships of 76 fish species from the Gulf of Cadiz (SW Spain). Fisheries Research 127-128: 171-175. DOI: 10.1016/j.fishres.2012.02.001

Wootton J. R. 1990. Ecology of teleost fishes. Fish and Fisheries Series No. 1. Chapman and Hall, London, UK. DOI: 10.1007/978-94-009-0829-1

Received: 14 July 2016 Accepted: 7 March 2018 Published electronically: 30 June 2018 